\title{
Commentary: Double-negative $T$ cells in the injured lung—evils or angels?
}

\author{
Alexander Sasha Krupnick, MD, and Yizhan Guo, MD
}

\footnotetext{
From the Department of Surgery, University of Virginia School of Medicine, Charlottesville, Va; and Carter Immunology Center, University of Virginia School of Medicine, Charlottesville, Va. Disclosures: Authors have nothing to disclose with regard to commercial support.

Received for publication Aug 26, 2019; revisions received Aug 26, 2019; accepted for publication Aug 27, 2019; available ahead of print Sept 23, 2019.

Address for reprints: Yizhan Guo, MD, University of Virginia, PO Box 800679, Charlottesville, VA 22908 (E-mail: yg2j@virginia.edu).

J Thorac Cardiovasc Surg 2021;161:e91

$0022-5223 / \$ 36.00$

Copyright (C) 2019 by The American Association for Thoracic Surgery

https://doi.org/10.1016/j.jtcvs.2019.08.132
}

Ischemia-reperfusion injury (IRI) of lungs, known as primary graft dysfunction of lung allografts, has been widely studied by lung transplant researchers. ${ }^{1,2}$ Despite the central roles that $\mathrm{CD}^{+}{ }^{+} \mathrm{T}$ helper cells and CD8+ effectors play in mediating allograft rejection, other T-cell subpopulations may attenuate organ damage, for example, regulatory $\mathrm{T}$ cells promote recovery for $\mathrm{IRI}^{3}$ and central memory $\mathrm{CD}^{+} \mathrm{T}$ cells are critical to lung allograft tolerance. ${ }^{4}$ This gives rise to the question that whether other T-cell populations such as $\gamma \delta \mathrm{T}$ cells and double-negative $\left(\mathrm{CD} 4^{-} \mathrm{CD} 8^{-}\right)$ $\mathrm{T}$ cells could also have their impacts on this immunologic process. In this current paper, Hsu and colleagues ${ }^{5}$ from the lung transplant program of Johns Hopkins University demonstrate that interleukin-10-secreted $\mathrm{CD}^{-} \mathrm{CD} 8^{-}$ double-negative $\alpha \beta \mathrm{T}$ cells (DN T cells) increase in the lung after IRI, down-regulate the local immune response, and protect the lung from IRI.

Hsu and colleagues ${ }^{5}$ explored the profile of DN T cells after lung IRI injury and demonstrated that this cell population undergoes immediate aggregation following a 30minute warm ischemia period and a 3-hour reperfusion. Robust interleukin-10 production by this cell population facilitates regulatory T-cell function, ${ }^{6}$ thus attenuating T-cellmediated immunity. Moreover, adoptive transfer of DN T cells into these mice ameliorate the histologic changes of lung IRI, suggesting a protective role for this cell population.

Although the homeostasis, as well as mechanisms of DN T cells in response to lung injury, is not fully dissected, such data are in line with the emerging idea that certain subtypes of $\mathrm{T}$ cells, other than the well-known $\mathrm{CD}^{+}{ }^{+} \mathrm{T}$ helpers and $\mathrm{CD}^{+}$effectors, may also play important roles in orchestrating the pulmonary immune response. These data suggest that the balance between multiple cell populations may concurrently control the microenvironment at the site of inflammation and impact the outcome of multiple clinical

\section{References} rol. 2009;20:1744-53.

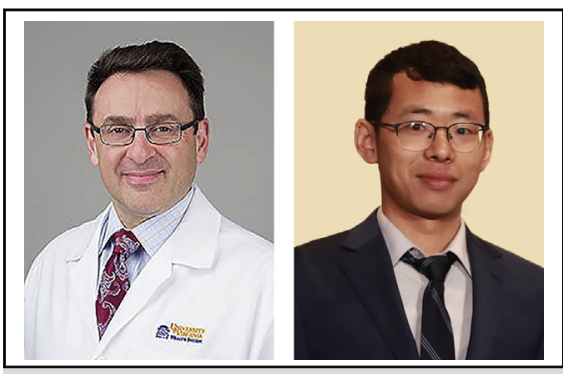

Alexander Sasha Krupnick, MD (left), and Yizhan Guo, $\mathrm{MD}$ (right)

\section{Central Message}

Double-negative $\alpha \beta$ T cells may be protective for lung ischemia-reperfusion injury via robust IL-10 productivity. This may challenge the conventional nonspecific immunosuppression therapies.

See Article page e81.

conditions such as IRI, acute, and even chronic rejection. This notion, extended to other models, could support the development of novel immunosuppression strategies form global and nonspecific ablation to that of precise immunomodulation based on targeted homing of defined cell populations to the lung graft.

1. Bharat A, Kreisel D. Immunopathogenesis of primary graft dysfunction after lung transplantation. Ann Thorac Surg. 2018;105:671-4.

2. Grimm JC, Valero V III, Kilic A, Magruder JT, Merlo CA, Shah PD, et al. Association between prolonged graft ischemia and primary graft failure or survival following lung transplantation. JAMA Surg. 2015;150:547-53.

3. Kinsey GR, Sharma R, Huang L, Li L, Vergis AL, Ye H, et al. Regulatory T cells suppress innate immunity in kidney ischemia-reperfusion injury. J Am Soc Neph-

4. Krupnick AS, Lin X, Li W, Higashikubo R, Zinselmeyer BH, Hartzler H, et al Central memory CD8 $+\mathrm{T}$ lymphocytes mediate lung allograft acceptance. $J$ Clin Invest. 2014;124:1130-43.

5. Hsu J, Krishnan A, Lee SA, Dodd-OJM, Kim BS, Illei P, et al. CD3+CD4-CD8double-negative $\alpha \beta$ T cells attenuate lung ischemia-reperfusion injury. J Thorac Cardiovasc Surg. 2021;161:e81-90.

6. Bharat A, Fields RC, Trulock EP, Patterson GA, Mohanakumar T. Induction of IL10 suppressors in lung transplant patients by CD $4+25+$ regulatory $\mathrm{T}$ cells through CTLA-4 signaling. J Immunol. 2006;177:5631-8.

7. Guo Y, Wang Q, Li D, Onyema OO, Mei Z, Manafi A, et al. Vendor-specific microbiome controls both acute and chronic murine lung allograft rejection by altering CD4(+) Foxp3(+) regulatory T cell levels. Am J Transplant. 2019;19:2705-18. 